ISLAM AND $_{\text {AN }}$

RELIGIOUS

EXPRESSION

${ }^{\mathrm{IN}}$ MALAYSIA 
The ISEAS - Yusof Ishak Institute (formerly Institute of Southeast Asian Studies) is an autonomous organization established in 1968. It is a regional centre dedicated to the study of socio-political, security, and economic trends and developments in Southeast Asia and its wider geostrategic and economic environment. The Institute's research programmes are grouped under Regional Economic Studies (RES), Regional Strategic and Political Studies (RSPS), and Regional Social and Cultural Studies (RSCS). The Institute is also home to the ASEAN Studies Centre (ASC), the Temasek History Research Centre (THRC), and the Singapore APEC Study Centre.

ISEAS Publishing, an established academic press, has issued more than 2,000 books and journals. It is the largest scholarly publisher of research about Southeast Asia from within the region. ISEAS Publishing works with many other academic and trade publishers and distributors to disseminate important research and analyses from and about Southeast Asia to the rest of the world. 


\section{ISLAM AND}
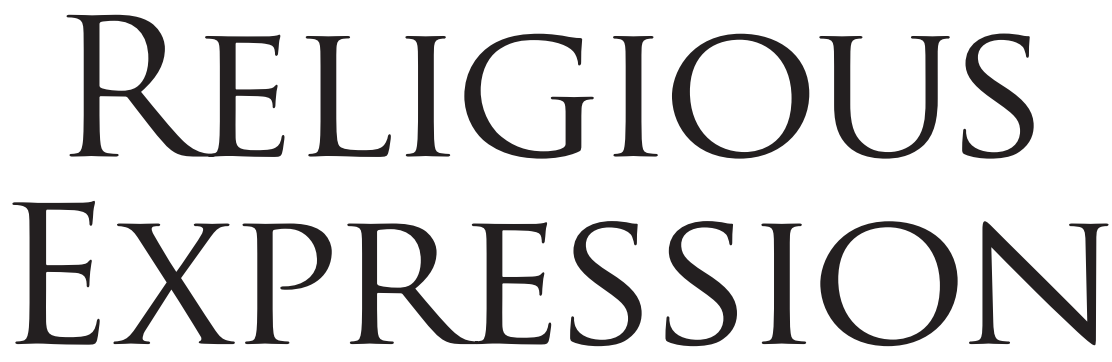

${ }^{\text {IN MALAYSIA }}$

MOHD AZIZUDDIN MOHD SANI 
First published in Singapore in 2020 by

ISEAS Publishing

30 Heng Mui Keng Terrace

Singapore 119614

E-mail: publish@iseas.edu.sg

Website: <http://bookshop.iseas.edu.sg>

All rights reserved. No part of this publication may be reproduced, stored in a retrieval system, or transmitted in any form or by any means, electronic, mechanical, photocopying, recording or otherwise, without the prior permission of the ISEAS - Yusof Ishak Institute.

(c) 2020 ISEAS - Yusof Ishak Institute, Singapore

The responsibility for facts and opinions in this publication rests exclusively with the author and his interpretations do not necessarily reflect the views or the policy of the publisher or its supporters.

\section{ISEAS Library Cataloguing-in-Publication Data}

Name(s): Mohd. Azizuddin Mohd. Sani.

Title: Islam and religious expression in Malaysia / by Mohd. Azizuddin Mohd. Sani. Description: Singapore : ISEAS - Yusof Ishak Institute, 2020. I Includes bibliographical references and index.

Identifiers: ISBN 978-981-4881-35-7 (paperback) | ISBN 978-981-4881-36-4 (PDF)

Subjects: LCSH: Freedom of speech-Religious aspects-Malaysia. I Islam and civil society-Malaysia. I Islam and state-Malaysia. I Radicalism-Religious aspects-Malaysia.

Classification: LCC BL65 F74A99

Typeset by Stallion Press (S) Pte Ltd

Printed in Singapore by Markono Print Media Pte Ltd 